\title{
Christopher J. Greig Ontario Boys: Masculinity and the Idea of Boyhood in Postwar Ontario, 1945-1960
}

Waterloo, Ontario: Wilfrid Laurier University Press, 2014. 182 pp.

\begin{abstract}
Jason Reid
Ryerson University
\end{abstract}

Christopher J. Greig's new book examines public discourses on boyhood in Ontario during the years following the Second World War. Greig argues that a host of journalists, child-rearing experts, and novelists (among others) used boyhood as a means of rejuvenating patriarchal structures that had been challenged by the decline of the male breadwinner ideal during the Great Depression and the increased participation of women in the workforce during the war. Indeed, if the commentators in Greig's study are to be believed, the creation of a rugged "boy citizen" who could "promote and protect democracy" was necessary in order to stave off a serious crisis of masculinity (xix).

Greig's study begins by looking at the extent to which boyhood was dependent on a stable home life. According to most observers, the ideal boy came from a white, middle-class, Protestant environment in which traditional gender roles were held sacrosanct. Mothers, for instance, were expected to stay at home to look after the children, while fathers were expected to be friendly and gentle, yet firm when the situation called for it, and willing to protect male children from their mother's overprotective ways. This vision of family and boyhood, Greig argues, represented a concerted attempt to "reconstruct patriarchal and heterosexist relations" (25).

The second chapter shifts to a discussion of teamwork and its importance in shaping modern boyhood. Greig suggests that the culture's intense emphasis on cooperation and loyalty to group structures - expressed most often through sports, Boy Scouts, summer camp, and other types of organized activities - was a response to the growing corporatization of the postwar economy, a means of countering fears of communism and labour unrest by instilling a corporatist ethos into the minds of the boys who would one day guide the Ontario economy. Even informal boy 
gangs - though not, it should be noted, the non-Anglo variations that were often associated with urban crime - were portrayed in positive terms, acting as a "model for corporate or factory life" (48).

The next chapter looks at how the discourse on boyhood was influenced heavily by heroic narratives. Once again, Greig places his arguments within the context of the corporate structure that defined life in postwar Ontario. The ideal boy was expected to be somewhat of an individualist and have a healthy respect for entrepreneurial activities, both of which were recast in a heroic light in order to complement the collective goals associated with modern corporations. Led by the businessmen and middle-class professionals who presided over the postwar corporate structure, the Boy Scouts are given special emphasis here, as Greig argues that they combined the conformity of the corporate world with the rugged individualism and love of nature that was associated with boy culture during the nineteenth century.

The most interesting chapter in Greig's book involves the types of boys who fell outside the white, middle-class, Protestant milieu that so often defined the discourse. Perhaps not surprisingly, poorer, non-Anglo, urban-dwelling boys were cast as the "Other," as a group of "bad boys" that were adventurous, yet lacking in self-control. Commentators often responded to this variation of boyhood by encouraging the creation of organized athletics and boys' clubs, both of which were given the task of preventing their charges from lapsing into delinquency or perversion. Vocational schooling was also offered, a trend that Greig interprets (rightly so) as a reflection of class bias within the discourse. Whereas the ideal boy was being prepared to take a leadership role in the corporate structure, the best a so-called "bad boy" could hope for was a spot at the bottom of the corporate hierarchy as an unskilled or semi-skilled worker.

Greig's final chapter is, admittedly, a bit troublesome, as it discusses current views on masculinity and how boyhood is once again being used as a means of reconstituting a more conservative social order. To be sure, Greig makes a noble attempt at linking his earlier points on boyhood to more contemporary debates on the subject. In the end his analysis is undermined somewhat by the fact that he tries to contemporize his arguments while ignoring the fifty-plus years of history that took place between 1960 (where his analysis ends) and the present. In other words, Greig's final chapter would have been more germane to what preceded it had he examined the entire postwar era rather than the fifteen years immediately following the end of the Second World War.

Another criticism I have involves the sources Greig uses to craft his arguments. His analysis of boyhood is limited to printed material that was published between 1945 and 1960 - most notably newspapers, magazines, scholarly material, and the odd novel. While his handling of this material is above reproach, Greig's arguments could have been strengthened somewhat by discussing how ideas on boyhood played out on television, film, radio, and popular music. After all, this was the era of Leave It To Beaver, children's Saturday matinees, and the growing popularity of rock ' $n$ ' roll. It would have been nice, in short, to see how ideas on boyhood made appearances in other types of popular culture, many of which targeted youth of all ages in a fairly aggressive manner. 
Ultimately, Ontario Boys represents a valuable contribution to the literature on boyhood, its strengths far outnumbering its weaknesses. It not only provides scholars with several strong arguments on how masculinity shapes our understanding of boyhood, but it does so in an engaging and well-written manner. By the same token, however, Greig's work could stand to be a bit more expansive in terms of its chronology and the types of sources it employs. It would have been interesting, for example, to see how the discourses on boyhood found expression in other media, and how they were challenged and/or reinforced as a result of the social upheavals of the 1960s, 1970s, and 1980s. 